\title{
Familial atrial myxoma
}

INSERM

\section{Source}

INSERM. (1999). Orphanet: an online rare disease and orphan drug data base. Familial atrial myxoma. ORPHA:615

Familial atrial myxoma is a rare, genetic cardiac tumor characterized by the presence of a primary, benign, gelatinous mass located in the atria and composed of primitive connective tissue cells and stroma (resembling mesenchyme) in several members of a family. Clinical presentation depends on the size, mobility and location of tumor, ranging from nonspecific and/or constitutional symptoms to sudden cardiac death, and includes dyspnea, hemoptisis, syncope, fatigue, fever, cutaneous rash, increases in venous pressure and/or peripheral edema. 